\title{
Thermal and visual comfort assessment of natural ventilated office buildings in Europe and North America
}

Article

Accepted Version

Creative Commons: Attribution-Noncommercial-No Derivative Works 4.0

Costanzo, V. and Donn, M. (2017) Thermal and visual comfort assessment of natural ventilated office buildings in Europe and North America. Energy and Buildings, 140. pp. 210-223. ISSN 0378-7788 doi: https://doi.org/10.1016/j.enbuild.2017.02.003 Available at https://centaur.reading.ac.uk/69074/

It is advisable to refer to the publisher's version if you intend to cite from the work. See Guidance on citing.

To link to this article DOI: http://dx.doi.org/10.1016/j.enbuild.2017.02.003

Publisher: Elsevier

All outputs in CentAUR are protected by Intellectual Property Rights law, including copyright law. Copyright and IPR is retained by the creators or other copyright holders. Terms and conditions for use of this material are defined in the End User Agreement.

www.reading.ac.uk/centaur

\section{CentAUR}


Central Archive at the University of Reading

Reading's research outputs online 


\section{Accepted Manuscript}

Title: Thermal and visual comfort assessment of natural ventilated office buildings in Europe and North America

Authors: V. Costanzo, M. Donn

PII: S0378-7788(17)30368-7

DOI: http://dx.doi.org/doi:10.1016/j.enbuild.2017.02.003

Reference: ENB 7363

To appear in: $E N B$

Received date:

9-5-2016

Revised date: 22-10-2016

Accepted date: $1-2-2017$

Please cite this article as: V.Costanzo, M.Donn, Thermal and visual comfort assessment of natural ventilated office buildings in Europe and North America, Energy and Buildings http://dx.doi.org/10.1016/j.enbuild.2017.02.003

This is a PDF file of an unedited manuscript that has been accepted for publication. As a service to our customers we are providing this early version of the manuscript. The manuscript will undergo copyediting, typesetting, and review of the resulting proof before it is published in its final form. Please note that during the production process errors may be discovered which could affect the content, and all legal disclaimers that apply to the journal pertain. 
Thermal and visual comfort assessment of natural ventilated office buildings in Europe and North America

\author{
V. Costanzo ${ }^{1}$, M. Donn ${ }^{2}$ \\ ${ }^{1}$ School of Construction Management and Engineering, University of Reading, Whiteknights, PO \\ Box 219, Reading, Berkshire, UK \\ ${ }^{2}$ Centre for Building Performance Research (CBPR), School of Architecture, Victoria University, \\ Wellington 6001, New Zealand
}

Keywords: office buildings, natural ventilation, thermal comfort, daylight, parametric analysis 


\section{Highlights}

- Natural ventilation viability and daylight use are explored for archetypical office buildings

- A new approach combining CFD, thermal and daylighting simulations has been developed

- A parametric analysis shows the connections between buildings and streets layouts

- Optimal values of WWR, UAR and floor width are found for different climates 


\begin{abstract}
Natural ventilation has the potential to significantly improve indoor comfort conditions and provide good indoor air quality by increasing both the indoor air velocity and the rate of air changes inside the building.
\end{abstract}

However, the performance of this technique strongly depends on various parameters, such as climate, urban form and building characteristics (geometrical and thermal).

With the aim of showing how natural ventilation can be successfully applied to existing office buildings in many different urban climates, an extensive parametric study has been carried out that takes into account the factors most likely to be relevant. Firstly, a characterization of different climates and the cities representative of them has been developed. Then, representative office buildings for each city have been modelled both in their base configurations and when natural ventilation is employed, in representative urban configurations.

This task has been accomplished by coupling three different simulation tools in an integrated approach. CFD, thermal and daylighting simulations allowed exploration of which are the most relevant parameters that affect thermal comfort and have some implications on visual comfort as well.

The large number of models simulated (almost 13 thousand) also provided the team with the opportunity to develop a new methodology for finding the best performing thermal models, based on Givoni's thermal comfort theory rather than monthly or annual energy needs.

\title{
1. Introduction
}

Passive solar design, natural ventilation and advanced daylighting measures have been shown to improve a building's energy performance in the areas of heating, cooling and lighting [1]. Traditionally, natural ventilation has been intended simply as a way to bring fresh air from outside to indoor spaces to dilute different pollutants generated inside the building (e.g. $\mathrm{CO}_{2}$, VOC compounds, $\mathrm{NO}_{\mathrm{x}}$ ), and to this aim, prescriptions about minimum air change rates are devoted [2]. However, natural ventilation can be successfully used also for maintaining summer temperatures within a comfort band, provided that much higher ventilation rates than ones needed for fresh air provision can be experienced.

Several works on this topic have focused on a building scale, providing design specifications for maximizing air flow rates and envelope thermal performance. For example, Belleri et al. [3] carried 
out a parametric analysis for a prototypical office building by varying the parameters mostly affecting the building response to solar and internal gains; Stabat et al. [4] reviewed previous singlesided ventilation studies by pointing out the different performances to be expected for various building loads, thermal inertia, orientations and window type combinations. Stavrakakis et al. [5] analyzed natural cross-ventilation effects on a test chamber by means of both experimental measurements and accurate CFD simulations, while Yao et al. [6] developed a coupled thermal and airflow calculation method - called the Thermal Resistance Ventilation (TRV) model - for assessing the potential of natural ventilation at the pre-design stage with reasonable accuracy by taking into account different climates, building specifications and ventilation profiles. The spotlight on the building scale is so common because it is conventional to assume that such a design approach cannot be easily achieved in urban scale buildings, and particularly in retrofit. This is because the dense nature of urban developments reduces both the availability of daylight - due to mutual shading - and the opportunities for more effective (wind driven) natural ventilation [7]. Neglecting the effects stemming from building management in naturally ventilated office buildings, although these are proved to be important in achieving the expected design performance of this passive cooling technique [8], the present paper furthers the discussion on the topic by considering not only the role played by several building features, but also different climates and urban settings. The main goal is to assess the potential for natural ventilation and daylight to improve the performance of typical urban buildings in Europe and North America.

First a set of typical urban areas were chosen to represent types of climate encountered in Europe and North America; a review of the online plans of these urban areas then informed the selection of street orientation and street width for the performance simulation models.

Next, a typical building form was defined, based upon the published empirical surveys of buildings in the EU [9] and in the US [10], respectively.

This was then brought together with data from these same surveys about the physical properties of the buildings surveyed, as well as their expected occupancy.

From all this data, a set of interlocking building performance models was constructed. At the heart of this set of models was a definition of a typical 3-storey building, surrounded by other buildings of a similar size and spaced from them by streets that were of the same size and orientation as the streets in each representative climate's urban area.

The Urbawind [11] Computational Fluid Dynamics (CFD) software was first used to model the typical relationship of the representative urban building and its surroundings to the winds in this climate. 
The Daysim interface to the Radiance Backwards Ray Tracing daylight analysis software [12] was then used to calculate the daylight availability within the representative urban building for every daylight hour of the year and for all floors in the building.

Finally, an EnergyPlus [13] thermal performance simulation model of the representative building was run for all 8760 hours of each Typical Meteorological Year weather file [14] representative of each urban area. Every EnergyPlus model took as input: a 3D model of the building oriented as the streets are in each representative urban area; the sun shading from the buildings defining the surrounding streets; the matrix of wind pressure coefficients (from Urbawind) for the different predominant winds for determining natural ventilation air flows; and the grid per thermal zone of daylight availability (from Daysim) which was used to determine when the lights could be turned off/on each hour of the day that the daylight was sufficient.

In order to study then the feasibility of natural ventilation, these representative urban buildings were parametrically varied within their representative urban areas to determine by how much the façade needed to change in order to maximise the use of daylight as a replacement for electric lighting and the use of openable windows for natural ventilation. The criteria for this optimisation was not the simplistic application of an overall energy performance for heating and cooling. Rather, the buildings were optimised for passive performance. This required that:

i. The optimisation process sought to maximise spatial Daylight Autonomy (sDA) - a measure of the quantity of daylight above a level deemed sufficient for the task over the whole building. Potential glare occurrences have been studied in terms of Annual Sunlight Exposure (ASE); ii. The thermal simulation sought to ensure that the building without heating or cooling equipment maximised the number of hours that the interior was maintained within a pre-determined comfort range based upon the work of Givoni [15].

The overall aim of this extensive parametric study was to find the most relevant features, both at urban and building scales, which affect each representative building's passive or intrinsic performance from the perspective of occupant comfort and natural ventilation viability. How these factors influence also daylight availability is discussed by showing the interaction between the modelled building and its close surroundings.

\section{Material and methods}

In the following paragraphs, different climates and ages of construction representative of the range of climate types in Europe and North America are reviewed. Then office buildings that are representative of each of these climates and urban layouts are developed. Finally, various building features are reviewed as likely influences on passive performance. The goal is to determine a range 
of representative data for input to the air flow, lighting and thermal simulation tools to parametrically estimate the thermal and visual performances expected from different configurations.

\subsection{Building Characteristics - climates}

In order to study the climatic parameters that affect natural ventilation performance, 5 cities representative of different US climate zones [16] have been chosen, together with 5 EU cities that show similar climatic conditions.

For the sake of comparison, a combined approach has been adopted that takes into account the Givoni [15] charts graphed in the psychometric format [17] and the summer monthly averaged values of dry bulb temperature, relative humidity, wind speed and global horizontal radiation - as gathered from TMY2 weather files [14]. The updated Köppen-Geiger climate classification [18] is too simplistic for comparing the effects of the climates of different cities scattered all over the world on passive building performance. Köppen-Geiger focuses on the outdoor environment very much from a plant physiology viewpoint; what is needed in building physics is a focus on the likely effect of the Air Temperature, Humidity, Wind Speed and Solar Radiation on the performance of a particular building. For example, if a building is a small house, with a small internal heat gain from people and lights, and a high heat loss surface area relative to its surface area, then a cool climate might well require mostly heating; but if it is large office building with a large internal heat gain from people and lights and a small surface area relative to its conditioned volume the same KöppenGeiger 'cool' climate would still lead to a requirement that the building mostly needs cooling to get rid of the internal heat gains.

Table 1 lists the cities selected using this approach. Their latitude (LAT), longitude (LON), Heating Degree Days (HDD) and Cooling Degree Days (CDD) are shown. The HDD and CDD were calculated on a baseline of $18.3^{\circ} \mathrm{C}$, according to the Climate Design Data 2009 ASHRAE Handbook [19].

The proposed classification is consistent with the International Climate Zone Definitions reported in ANSI/ASHRAE/IESNA Standard 90.1-2007 [20], which assigns a zone name according to a thermal criteria based on HDD and CDD.

Table 2 lists the summer monthly (from June to September) and winter (January to March) averaged values of a selection of representative climate variables.

The rationale for selection of these cities to test the potential for Natural Ventilation in Europe and North America is:

i. Europe is Western Europe, comprising countries within the bounds of 10 degrees West to 20 degrees East Longitude and +35 to +60 degrees North Latitude; 
ii. North America is of broadly similar Latitudes: +35 to +60 degrees North; but from a much wider 75 to 125 degrees West Longitude range;

iii. A range of cooler and warmer climates facing different 'Koppen-Geiger' style climate issues;

iv. Representation of latitudes and hence climates where the population is concentrated in each continent as illustrated by Figure 1. Here the color of the arrows corresponds to the climate classification shown in Table 1 (from the coldest climates pointed with dark blue arrows to the hottest ones with red arrows), while the segment length represents the proportion of the population density in each region.

Figure 1

Table 1

Table 2

Part of the classification of the climates involved also a visual examination of the Typical Meteorological Year (TMY) data for each city on a psychrometric chart using the Climate Consultant software [21]. Here, pairs of temperature (x-axis)/relative humidity (curves) points for every hour of the year are plotted using scale colors varying from dark blue points for the coldest hours to red points for the hottest.

It is clear from these charts that the much greater extremes of climate that the Koppen-Geiger approach is intended to document are not found in Europe or the USA. Comparing the charts for Albuquerque and Madrid in Figure 2, with the pattern of the Koppen-Geiger 'Hot Dry' climate of Riyadh in Figure 3, it is clear that in the North American and European hot dry cities there are far more cold than hot hours in the year.

Figure 2

Figure 3

This can also be seen in the comparisons of the 8760 temperature and humidity pairs for a genuinely hot humid climate such as Hawaii in Figure 4, with the patterns for Atlanta and Rome 
(Figure 5). There is a clear period in the cities used in this study when the temperatures and humidities are 'tropical' $-15 / 16 \%$ of the time, compared to the $61 \%$ for Hawaii. However, for a much larger proportion of the time $(61 / 68 \%$ cf $5 \%)$ the temperatures are below $20^{\circ} \mathrm{C}$.

Figure 4

Figure 5

These trends are the same for all the cities in the study (Table 3). The simplistic climate typologies are at best indications of the issues. If we add to this the high internal heat gains of the type of office building modelled here, then we arrive at yet another reason for this type of modelling study. This methodology could be usefully adopted in other researches when comparing buildings located in cities scattered all over the world.

Table 3

\subsection{Building Characteristics - age}

In order to gather reliable information about the existing office building stock, two extensive surveys have been used as references for the EU and US countries: the iNSPiRe project [9] and the US Department of Energy Commercial Reference Building Models of the National Building Stock [10], respectively.

Both these reports analyze the office building stock from the generic (total floor area, number of floors, type of tenure, occupancy schedules) and thermal (energy needs for air conditioning, ventilating, hot water production and artificial lighting) points of view, thus highlighting the best ways to improve their performance. 
The approach followed is thus based on the development of archetypal buildings, i.e. of buildings that are statistical composites of the main features found in a specific building stock as gathered from an extensive survey [22].

This method of modelling is a simplification of the variability found in real buildings. However, it does offer a fact-based means to identify a pattern representative of the vast majority of these buildings and thus to evaluate the potential of different solutions for passive cooling purposes. Within this framework, a time classification is also needed, since the focus of this study is on conversion of the existing buildings and most of these have been built over the past one hundred years. This is illustrated in Table 4 where it can be seen that approximately half of all buildings in both the EU and the US were constructed prior to 1980. The division into three classes of pre-1980, 1980-1999 and post 2000 ages is adopted from the DOE [10] reference periods of construction.

\section{Table 4}

\subsection{Building Characteristics - construction}

For each 'vintage' from Table 4, the construction typologies of the EU and the US are summarized in Table 5. The resulting U-values are shown in Table 6. It is noteworthy that there are significant differences - in each climate and for every construction type - between the corresponding US and EU cities, especially for the first two reference periods (pre-1980 and post-1980). The US construction U-values are often lower (from $30 \%$ up to 65\%) than the EU ones, as a result of the different building codes adopted. These differences are much less pronounced for the last reference period (new constructions).

When passing from one vintage period to another, and from one city to another within the EU or US respectively, the insulation thickness of the opaque components listed in Table 4 has been varied to achieve the U-values set by the relevant building codes. It is notable for example that although the 'typical construction' specifies double glazing in Pre-1980 buildings in both the EU and the US, the U-values for most of the cities at this time are for single glazing. The windows have been modelled inputting both their glazing thermal transmittance and their solar heat gain coefficient.

Table 5

Table 6 


\subsection{Building Characteristics - plan and form}

The geometrical layout of the sample office building model, in its base configuration, is shown in Figure 6. It represents a typical 3-storey open plan office building, with floors of $1000 \mathrm{~m}^{2}$ each and windows on the two main facades shaded by external horizontal overhangs. The external shading (purple surfaces in Figure 6) provided by nearby buildings on the two main facades is also modelled.

This geometric layout is consistent with the surveys cited above when considering medium to large existing office buildings, as well as with a recent IEA Task on the renovation of non-residential buildings [23] and the CBECS survey in US [24].

Figure 6

\subsection{Building characteristics - the city context}

The feasibility of daylighting and natural ventilation requires the modelling not just of the (purple) external solar shading surfaces from a heat gain or loss point of view shown in the Thermal Simulation illustration in Figure 6, but also the effect on the flow of air and on access to daylight from the sky of the urban context. An over-riding parameter for these studies therefore is the wind flow pattern determined by the urban layout that surrounds the building [7]. The Urban Aspect Ratio (UAR) is regarded as the parameter that takes into account the reduction of the wind pressure on the facades due to the surrounding buildings. It is defined as the ratio of the building height to the distance that separates it from the building opposite, and although its use alone cannot fully describe the complexity of an urban grid [25], it is deemed appropriate for studying regular layouts expected for Central Business District (CBD) zones. The values chosen in this paper take into account road widths that are very common for the CBD zones of the cities considered. These characteristic road widths were determined from a Google Street View review of the Central Business Districts of the study cities.

\subsection{Building characteristics - the study parameters}

Besides the building characteristics discussed in the previous paragraphs, which affect the thermal behavior of the building, other parameters were varied to examine the role they play on determining occupants' comfort conditions, and hence the feasibility of providing natural ventilation and daylighting in urban non-residential buildings in the EU and the US. 
The shape of the building was varied while retaining a floor area equal to $1000 \mathrm{~m}^{2}$. This was for the purposes of determining how deep an office building could be for natural ventilation purposes. From a starting value of $15 \mathrm{~m}$ depth based on a CIBSE [26] recommendation - which suggests wind penetration inside a room of about 5 times the ceiling height when cross ventilation is used - and on Lo Verso and Reinhart's [27] rule of thumb (which suggests a penetration distance for daylight ranging from 1.5 to 2.5 times the window height and noting these buildings are lit from two sides), this value is then increased up to $25 \mathrm{~m}$.

Window to Wall Ratio (WWR) values are chosen according to [9-10], while the overhang depth is defined by means of an overhang Projection Factor (PF, i.e. as a fraction of the shaded window height). The corresponding values used for this investigation are typical for office buildings and consistent with [28], where the effects of solar shading devices were studied.

Finally, the Window Opening Area (WOA) - defined as the percentage of glazed surface that can be opened - is taken into account. Values ranging from 0.10 to 0.30 are considered, according to previous studies on this topic [29-30].

All these parameters are summarized in Table 7, showing their values, the number of variations for each one and the resulting number of cases for each city. They represent the basis for carrying out two 'families' of simulations: one for the base models and one for the models that use natural ventilation (WithVent models).

The final number of models simulated (base + WithVent cases) is thus given by the sum of the cases considered for each city, and is equal to 12960.

Table 7

\section{Simulations framework: tools and metrics adopted}

This study necessitated the integration of different specialist simulation tools. The estimation of the average wind pressure coefficients $\left(\mathrm{C}_{\mathrm{p}}\right)$ acting on the two main facades - for each storey - was carried out using the UrbaWind software; these coefficients were employed as input to EnergyPlus for the evaluation of the driving forces for the natural ventilation network and its effect on the annual thermal behaviour of the building. Similarly, Daysim was employed to determine the availability of daylight and the percentage of each floor whose electric lights could be switched off and provided as an input to the corresponding EnergyPlus thermal models. 
Simulations for both the base cases and the ones using natural ventilation were performed, thus showing the benefits originating from the use of this passive cooling technique.

A flow chart that summarizes the simulation framework and the outputs generated by each tool is given in Figure 7 and discussed in detail in the following paragraphs.

\section{Figure 7}

\subsection{CFD analysis}

Generally speaking, pressure coefficients $C_{p}$ relate the static pressure at a given point on a façade $P_{x}$ (which is defined as an 'external node' in the nodal network used by EnergyPlus, see Section 3.2) to the reference static $\left(\mathrm{P}_{\mathrm{ref}}\right)$ and dynamic $\left(\mathrm{P}_{\mathrm{dyn}}\right)$ pressure. This relation is shown in Equation 1:

$$
C_{p}=\frac{P_{x}-P_{r e f}}{P_{d y n}}
$$

In [31] Grosso identified four different approaches for calculating these coefficients: full scale measurements on existing buildings, wind tunnel tests on scale models, numerical models based on existing wind tunnel tests results and 3D numerical airflow models (CFD simulations). Given the high computation power achieved by personal computers in the last years, as well as the ease of use compared to the other methods, CFD simulations with Urbawind [11] have been carried out for each city and UAR value.

Because the main orientation of the CBD streets and their UAR was different for each city considered, the CFD/wind analyses were performed for each city individually.

These individual wind analyses were conducted because, as highlighted in [32], a wrong estimation of the wind pressure coefficients can lead to differences up to $15 \%$ in the predicted air change rates and thus to a wrong estimation of the cooling energy savings.

The relevant parameters for each city were then inferred from aerial GoogleMaps views. These views identified the four main building orientations summarized in Table 8 . The rotation value assigned to the models of each city, with respect to the north direction, is representative of the respective $\mathrm{CBDs}$ within a tolerance of $\pm 10^{\circ}$. 
For each resulting model, a medium mesh resolution $(1 \mathrm{x} 1 \mathrm{~m}$, with refinements of $0.5 \mathrm{~m}$ near building surfaces and of $0.3 \mathrm{~m}$ near the ground) and a high-density city inlet wind profile have been chosen. These values were found to be sufficiently precise for the purpose of this study, whilst leading to practical calculation times, as a test revealed that choosing the finest mesh resolution allowed by the software altered the results by less than $5 \%$ for almost all wind directions while substantially increasing (up to 4 times) the simulation time.

The nearby buildings, under the hypothesis of a homogenous CBD layout, have been modelled with the same geometrical features of the sample one (a row of buildings on each side, see Figure 8). This represents a very common urban layout for the cities considered, and one of the worst spatial configurations for natural ventilation purposes in an urban environment, as highlighted in [33]. The directional step for the computation is set to $45^{\circ}$ (one $C_{p}$ value every $45^{\circ}$, measured clockwise from the outward normal to the surface). All 8 resulting matrices of pressure coefficients were provided as input to the EnergyPlus [13] thermal simulation program.

Figure 8

\subsection{Thermal analysis}

The metrics associated with the thermal analysis were the operative temperature $\left({ }^{\circ} \mathrm{C}\right)$ and relative humidity (\%), used for comfort assessment, and the Air Changes per Hour (ACH) and the indoor air $\mathrm{CO}_{2}$ concentrations (ppm) that provided an indication of Indoor Air Quality (IAQ).

They were calculated with an hourly time step using EnergyPlus [13]. Together with the graphical interface and users' scripts provided by OpenStudio 1.4.0 [34], it is possible to accurately model natural ventilation using the nodal approach of the AirFlowNetwork model (AFN).

This nodal approach has proved to be very effective [35-36], especially if coupled with an external source for the estimation of $\mathrm{C}_{\mathrm{p}}$ coefficients. EnergyPlus was set up to select the most suitable $\mathrm{C}_{\mathrm{p}}$ values calculated for various wind directions by Urbawind, according to the hourly wind directions provided in the TMY2 weather files.

A summary of the simulation assumptions is provided in Table 9.

Table 9 
For the WithVent cases, an external node for each opening - placed at a height from the ground equal to the height of the windows centroid - was defined. For each node, $\mathrm{C}_{\mathrm{p}}$ coefficients derived from CFD simulations were used.

The openings were horizontally pivoted windows controlled by a zone sensor (one per floor) that controls their aperture throughout the day if the following conditions are met together:

$$
\left\{\begin{array}{l}
1<T_{\text {zone }}-T_{\text {out }}<15 \\
23<T_{\text {op }}<27 \\
A C H<25
\end{array}\right.
$$

This kind of control should avoid both an inflow of outside air that is too warm/too cold and a likely discomfort due to high air speeds inside the rooms.

Moreover, a linear modulation of the openings is provided within the range $1<\mathrm{T}_{\text {zone }}-\mathrm{T}_{\text {out }}<15$, with a minimum opening factor of zero (windows closed) when the above temperature difference is more than $15^{\circ} \mathrm{C}$. In this way, minimum $\mathrm{ACH}$ are still often met, meaning that building's air tightness is overestimated in the simplified approach followed in [9-10], thus remarking the need for a more precise estimation of the airflow in buildings. This is in agreement with what has been found by $\mathrm{Ng}$ et al. [37] when modelling air infiltrations in US commercial reference buildings. The opaque components of the envelope have been treated as cracks with air mass flow coefficient of 1 and air mass flow exponent of 0.5 , as suggested during the simulations for stability issues. The floor chosen for the thermal analysis is the intermediate one, in order to exclude boundary effects typical of ground and top floors.

\subsection{Daylighting analysis}

The dynamic metrics chosen are the spatial Daylight Autonomy (sDA) and Annual Sunlight Exposure (ASE), as recently defined by the Illuminating Engineering Society of North America (IES) [38].

The sDA is a metric that measures annual sufficiency of ambient daylight levels, while ASE describes the potential for visual discomfort from direct sunlight.

The daylighting analyses were carried out with the help of the software Daysim, which is based on the Radiance backward raytracing and Tregenza's Daylight Coefficients methods that are widely considered the state of the art when modelling daylight [39-40]. 
The tabular results from Daysim can be imported in EnergyPlus as a schedule for estimating the artificial lighting loads in a more precise way than the inbuilt EnergyPlus SplitFlux method does [41].

These calculations are performed with a 5 minutes time step assuming a visible transmittance of 0.78 for double-glazed windows, while the following visible reflectance values are assumed for the opaque surfaces:

- $\quad$ ground: 0.2 ;

- $\quad$ nearby buildings: 0.3 ;

- $\quad$ overhangs: 0.4 ;

- $\quad$ floor: 0.2 ;

- $\quad$ walls: 0.6 ;

- $\quad$ ceiling: 0.8

The reference grid of points for the calculation of the illuminance values has been chosen, according to the 3 different floor dimensions, in a way that each sensor point controls approximately $5 \%\left(50 \mathrm{~m}^{2}\right)$ of the floor area. In this way, computation times are not too high and a good spatial resolution is still achieved. A plan view of these grids is given in Figure 9.

Figure 9

\section{Results and Discussion}

This Section presents the results of the simulations in the same order as the analyses described in Section 3: the $\mathrm{C}_{\mathrm{p}}$ values gathered from CFD analysis for different urban configurations (Section 4.1) provide the basis for modelling the effect of natural ventilation on the buildings (Section 4.2). Here, the comparison amongst the best thermal models of each city for both the base and WithVent cases highlights which are the features that most influence the ventilation potential. Finally, the daylighting analysis for the best thermal models is reported in Section 4.3, showing how daylight availability is affected by different geometrical configurations.

\subsection{CFD results}

As noted in Section 3.1, the Urban Aspect Ratio (UAR) was regarded as the parameter most likely to influence the natural ventilation potential within a regular urban environment. Considering the 4 different values chosen for this parameter, and the different CBD orientations for each city as shown in Table 8 , this led to 16 different models. For each of them, surface averaged $\mathrm{C}_{\mathrm{p}}$ values 
were gathered for every window considering a wind incident angle step of $45^{\circ}$ (i.e. the clockwise angle between the wind direction and the outward normal to the surface).

For the sake of brevity all the results are not shown here, but the values for two of the models are reported in Figure 10, where both different wind angles and urban layouts highlight the variability of $\mathrm{C}_{\mathrm{p}}$ coefficients and thus the expected performance for ventilation.

Figure 10

\subsection{Thermal results}

The aim of these simulations was to find out which are the parameters that mostly affect the ventilation potential and estimate the expected building performance for both the buildings that do not use natural ventilation (base models) and the ones that do (WithVent models), respectively. Given the number of almost 13 thousand models simulated, and the resulting amount of data, serious attention has been paid to find a way for presenting the results in a concise but weighty manner. As the purpose of this study was to examine thermal comfort, the results are presented in a format that graphically represents all relevant hours of the year on a psychrometric chart with annotations according to Givoni's comfort theory [15]. Only the best performing cases for each city are presented in this manner.

The criteria for 'best' was those that show the highest number of comfort hours, within the occupancy period, for an entire year. The goal was to determine how the best base models differ from the best ones using Natural Ventilation ('WithVent'), thus showing the venting benefits in each climate.

These results are shown in Figure 11. Pairs of indoor operative temperature-indoor relative humidity values are plotted within a Givoni annotated building bioclimatic chart for the base models (red dots) and the models employing natural ventilation (blue dots), for each climate and city analysed.

The Adaptive Comfort Criteria literature [42-44] suggests that people in buildings with controllable and openable windows for Natural Ventilation are more tolerant of higher indoor temperatures. Therefore, although the base models report a comfort zone outlined by the green box on the Givoni Charts, for the Natural Ventilation (the WithVent) cases, there is an extended comfort zone defined by the dashed green lines. This first comfort zone is suited for static air inside the room - which well represents the conditions found in pressurized offices - while the extended zone is good for evaluating comfort conditions when some movement is given to the indoor air, as when naturally ventilating. 
It is possible to see how ventilating the buildings always leads to a strong improvement in the indoor conditions (the number of comfort hours are always doubled if compared to the base case), despite the climate and the geographical area. The marine climates of London and Seattle are a slight exception as they experience good comfort conditions also in their base configurations. A closer look at Figure 11 shows also how seldom natural ventilation is not able to meet the comfort conditions. This happens for the marine and cold climates during winter (blue points outside of the comfort zone and inside the heating one) and for the hot humid/mixed humid climates during summer (blue points inside the cooling dehumidifying zone).

More interesting, the best cases shown in Figure 11 share some common building features in each climate: indeed, the best base models are those that employ well-insulated building components (new constructions) and a moderate amount of window surfaces $(0.3 \leq \mathrm{WWR} \leq 0.4)$, well shaded by external overhangs $(\mathrm{PF}=1)$ and by nearby buildings $(1 \leq \mathrm{UAR} \leq 2)$. This is consistent with the main issue of office buildings, i.e. limiting the amount of heat gains into the rooms in order to avoid overheating problems due to high internal heat sources (principally people, electric appliances and artificial lighting systems).

The best WithVent models are those with the smallest floor width $(15 \mathrm{~m})$, that employ new constructions for their opaque envelope and with $\mathrm{WWR}=0.3$. Overhangs are not necessary $(\mathrm{PF}=0)$, while UAR values are optimum between 0.5 and 1 . This means that on the one hand the buildings still need to be sheltered from the solar action (low values of WWR), but on the other hand the use of natural ventilation strategies could improve visual comfort $(\mathrm{PF}=0$, see Section 4.3 about daylighting results), thus reducing the internal gains due to artificial lighting.

The best conditions for cross ventilating also imply that nearby buildings are not too close to the one to be ventilated $(0.5 \leq \mathrm{UAR} \leq 1)$ - and this is in accordance with the results of CFD simulations about Cp coefficients (see Section 4.1) - while no significant differences are expected when varying WOA values, meaning that the most relevant window-related parameter still remains the WWR.

Figure 11

These data have subsequently been examined to determine whether sufficient fresh air is able to be provided by the naturally ventilated buildings to meet the design Indoor Air Quality (IAQ) values reached in the base configurations. This is clearly visible in the two upper rows of the matrix shown in Figure 12. Here the graphs depict how the supply ventilation measured in Air Changes per Hour $(\mathrm{ACH})$ varies for every simulated hour (x-axis). The data is based upon windows being opened to achieve sufficient fresh air from outside to maintain the target temperature levels reported in Eq. 
(2). For most of the time ACH are found to be sufficient: indeed, $\mathrm{ACH}$ are shown to be within the band 0-10 for most of the time, while being higher for a smaller period. The corresponding $\mathrm{ACH}$ values reached when ventilating by means of fixed values (base cases) would range from 0.30 to 0.65 in EU cities and from 0.15 to 0.65 in the US cities, according to their different occupancy profiles.

Lower ACH are achieved by marine climates (London and Seattle) because of the low temperatures frequently experienced during the year that lead the control system to keep the windows opened for less time than in other cities, thus explaining why for this climate the improvement in the comfort conditions is modest if compared to the others (see Figure 11).

It is possible to observe also how during the winter period (first and last parts of the graphs) the $\mathrm{ACH}$ rates were calculated to be lower than those achieved in the remaining part of the year because of the heating needs experienced - and conversely how they were higher in summer (central zone of the graphs).

Looking at $\mathrm{CO}_{2}$ concentrations during ventilation (Figure 12, two bottom rows), they always stayed well below $2500 \mathrm{ppm}$, which according to [45] is considered to be the threshold value above which decision-making tasks are significantly worsened.

The highest $\mathrm{CO}_{2}$ concentrations expected for the US cities (often within the band 1000-2500 ppm) are due to differences in the occupancy profile with the EU cities, having assumed the same outdoor concentrations (400 ppm) for all of the cities. Moreover, because of the less opening time of the windows in the marine climate, $\mathrm{CO}_{2}$ concentrations are expected to be slightly higher than those achieved in the other cities.

One should notice also that if the cities were significantly polluted, these $\mathrm{CO}_{2}$ concentrations could be worse than shown here.

On the other hand, the constant supply of outdoor fresh air for the base models is able to guarantee $\mathrm{CO}_{2}$ concentrations always below $1000 \mathrm{ppm}$, so we can infer that from an indoor air quality perspective $\mathrm{CO}_{2}$ concentrations are only slightly increased when naturally ventilating an office building.

\section{Figure 12}

\subsection{Daylighting results}

Visual comfort plays an important role in office buildings, where repetitive visual tasks have to be performed every day and where, typically, the office worker has little choice about where to sit to avoid glare and to optimize their use of daylight. It is well-known that daylight is preferred to artificial light in enclosed spaces, due to its role in stimulating biological functions as well as 
influencing humans psychologically [46], so there is a double incentive to evaluate the amount of daylight inside the building: energy savings through reduced electric light usage, and improved comfort.

The two dynamic metrics recently described in Section 3.3 and defined by the North American IES are written as: $\mathrm{sDA}_{300,50 \%}$ for Daylight Autonomy and $\mathrm{ASE}_{1000,250 \mathrm{~h}}$ for Annual Sunlight Exposure. The first one expresses the percentage of the visual task area (the building floor area in this case) that meets a minimum daylight illuminance level of $300 \mathrm{~lx}$ for at least the $50 \%$ of the analysis period, which is set to 3650 hours. The second one expresses the percentage of the same visual task area used for the previous calculation that exceeds $1000 \mathrm{~lx}$, due to direct sunlight illuminance, for more than 250 hours in a year. The results of the calculations are shown in Figure 13 and highlight how for existing office buildings daylight availability is very poor (not acceptable according to [38]), at least for the base cases. In fact, for these cases (red solid bars, primary y-axis) sDA is always well below the acceptable threshold value of 55\%, ranging from 5\% (Stuttgart) to 30\% (Albuquerque). The lowest values pertain to EU cities, for which the sDA is always reached in the first part of the day (from 8:30 AM to 3:30 PM), thus showing how the climate strongly affects daylit spaces.

Comparing the best base case with the optimal natural ventilation configuration in each city (blue solid bars, primary y-axis), daylight availability is always better in the latter case. This is most likely due to the optimal WithVent case requiring no external shading, as discussed in Section 4.2; there is likely to be a higher Daylight Availability for those situations where the WWR is increased, although an acceptable sDA is not yet achieved. Improving beyond this SDA 'score' would need to be the subject of specific design measures related to the actual physical situation, not a review of general principles as here. It does suggest that the design challenge in retrofit of buildings in these urban environments is greater for providing daylight than for natural ventilation.

As expected, because of poor daylight availability, potential discomfort situations due to direct sunlight illuminance (i.e. glare discomfort) is not an issue for the base cases, while for the other cases it could represent a problem. Indeed, ASE values (solid lines, secondary y-axis) are always better than the unsatisfactory threshold value of $10 \%$ for the base cases - being even below the clearly acceptable threshold of $3 \%$ for some configurations. They are consistently over it for cities such as Madrid, Atlanta, Baltimore and Seattle when natural ventilation is employed. The lesson to be drawn from this analysis is that in design of these natural ventilation retrofits it would be beneficial to provide reflective blinds or other simple forms of glare control that shade from direct sun but preserve reasonable levels of Daylight Autonomy $\left(\mathrm{sDA}_{300,50 \%}\right)$. Blinds, as movable and not permanent parts of the building design have not been modelled in this analysis. 
In conclusion, although daylight availability inside open plan office buildings that do not use specific daylighting devices is very poor because of their geometrical configuration, noticeable improvements in daylight levels could be achieved if adopting the best geometrical configurations suited for natural ventilation purposes.

Figure 13

\section{Conclusions}

Several cities representative of a range of climates in EU and US countries were studied for their suitability for the application of natural ventilation and daylight in the retrofit design of existing office buildings. They were selected to provide a wide representation of the climates in each region and to bracket the most likely urban situations. For each city, representative open plan office buildings located in CBD zones - whose characteristics are gathered from two surveys on the existing office buildings stock - have been considered as base cases for an extensive parametric analysis.

The variations took into account different urban grid layouts by means of streets orientation and the UAR parameter (with values ranging from 0.5 to 2), as well as different building features such as floor plate dimensions varying from $15 \mathrm{~m}$ (narrow buildings) to $25 \mathrm{~m}$ (depth plan) and construction periods representative of three age bands (pre-1980, post-1980 and post-2000).

Specific care has been paid to windows characteristics by considering three different WWR values (0.3, 0.4 and 0.5), WOA values (0.1, 0.2 and 0.3) and overhangs depths $(\mathrm{PF}=0, \mathrm{PF}=0.5, \mathrm{PF}=1)$. Building performance has been measured using comfort conditions and IAQ metrics during the office occupancy hours throughout the year. The goal was to assess the quality of the indoor environment during the full range of all occupied hours of the year, and not by means of simplistic monthly or annual energy use values.

Although the main objectives of this study are theoretical and aim at exploring and quantifying the relationships between building characteristics and urban layouts for natural ventilation viability and daylight use - therefore the use of archetypes and regular street grids - it is believed that its outcomes might may help both building designers and urban planners especially during the conceptual stage of retrofit interventions.

From almost 13 thousand simulations it is possible to conclude that natural ventilation represents a very effective way of improving comfort conditions inside existing office buildings, both in Europe and North America. Indeed, the number of comfort hours are expected to be higher when compared to the base cases (they are doubled in each climate, with a little exception for the marine climate 
where the base configurations already show good comfort conditions). Seldom are the comfort conditions not met when ventilating: some additional heating or cooling might be needed for a very few occupancy hours.

When ventilating, the air supply measured in $\mathrm{ACH}$ is found to be always sufficient for providing enough fresh air to the rooms, while only slightly increasing $\mathrm{CO}_{2}$ concentrations with respect to the base cases (i.e. when fresh air supply is achieved by means of fixed ACH values).

On the other hand, natural daylight availability remains an issue for open plan office buildings. In fact, in spite of the fact that the best building configurations for natural ventilation purposes significantly improve the sDA metric for each climate with respect to the base cases, less than $40 \%$ of the building floor area is expected to be successfully daylit for buildings with the dimensions found to be typical of the cities studied.

More interesting, the analyses highlight that the best building configurations for ventilation purposes are the same for each climate, thus providing useful suggestions when retrofitting existing premises. In detail, the optimal building configuration should present UAR values between 0.5 and 1, floor plate depths less than $20 \mathrm{~m}$ in the direction chosen for cross ventilating as well as well insulated envelope components (walls, roof and windows). As for the design of windows, the WWR should not exceed the value of 0.3 in order to reduce the amount of solar gains and avoid the use of external overhangs.

\section{References}

[1] WBDG: 'Optimize Energy Use' and 'Promote Health'.

https://www.wbdg.org/design/minimize_consumption.php and https://www.wbdg.org/design/promote_health.php. Last accessed: January 2016

[2] M. Fordham, Natural Ventilation, Renewable Energy 19 (2000) 17-37

[3] A. Belleri, S. Dutton, U. Oberegger, R. Lollini, A sensitivity analysis on natural ventilation design parameters for non-residential buildings. In: Building simulation, Chambery (2013)

[4] P. Stabat, M. Caciolo, D. Marchio, Progress on single-sided ventilation techniques for buildings, Advances in Building Energy Research 6 (2012) 212-241 
[5] G.M. Stavrakakis, M.K. Koukou, M.Gr. Vrachopoulos, N.C. Markatos, Natural crossventilation in buildings: Building-scale experiments, numerical simulation and thermal comfort evaluation, Energy and Buildings 40 (2008) 1666-1681

[6] R. Yao, B. Li, K. Steemers, A. Short, Assessing the natural ventilation potential of office buildings in different climate zones in China, Renewable Energy 34 (2009) 2697-2705

[7] R. Ramponi, I. Gaetani, A. Angelotti, Influence of the urban environment on the effectiveness of natural night-ventilation of an office building, Energy and Buildings 78 (2014) 25-34

[8] K. Watson, Understanding the role of building management in the low-energy performance of passive sustainable design: Practices of natural ventilation in a UK office building, Indoor and Built Environment 24 (7) (2015) 999-1009

[9] iNSPiRe Project reports D2.1a-D2.1c (2014). Survey on the energy needs and architectural features of the EU building stock. http://www.inspirefp7.eu/about-inspire/downloadable-reports/ Last accessed: March 2015

[10] NREL report (2011). U.S. Department of Energy Commercial Reference Building Models of the National Building Stock. http://energy.gov/eere/buildings/commercial-reference-buildings. Last accessed: March 2015

[11] S. Sanquer, G. Caniot, W. Li, D. Delaunay, A combined CFD-Network method for the crossventilation assessment in buildings. http://meteodyn.com/wp-content/uploads/2012/06/ICWE13_Acombined-CFD-Network-method-for-the-cross-ventilation-assessment-in-buildings-.pdf. Last accessed: March 2015

[12] C.E. Ochoa, M. Aries, J. Hensen, State of the art in lighting simulation for building science: a literature review, Journal of Building Performance Simulation 5 (4) (2012) 209-233

[13] US Department of Energy, EnergyPlus version 8.1, 2014. http://apps1.eere.energy.gov/buildings/energyplus. Last accessed: April 2015

[14] W. Marion, K. Urban, User's manual for TMY2s Typical Meteorological Years (1995). Retrieved on March 2015 on http://rredc.nrel.gov/solar/pubs/tmy2/ Last accessed: April 2015 [15] B. Givoni, Comfort climate analysis and building design guidelines, Energy and Buildings 18 (1) (1992) 11-23

[16] US Department of Energy. High-performance home technologies. Guide to determining climate regions by county (2010). http://www1.eere.energy.gov/library. Last accessed: April 2015 
[17] Vivian Loftness, Climate/energy Graphics: Climate Data Applications in Architecture. World Meteorological Organisation. (1982).

[18] M. Kottek, J. Grieser, C. Beck, B. Rudolf, F. Rubel, World map of the Köppen-Geiger climate classification updated, Meteorologische Zeitschrift 15 (3) (2006) 259-263

[19] ASHRAE. ASHRAE Handbook Fundamentals. Atlanta: American Society of Heating, Refrigerating and Air-Conditioning Engineers, Inc; 2009

[20] ANSI/ASHRAE/IESNA Standard 90.1-2007. Energy Standard for Building Except Low-Rise Residential Buildings.

[21] UCLA Energy Design Tools Group, Climate Consultant v.6.0, 2015.

http://www.energy-design-tools.aud.ucla.edu/ Last accessed: March 2015

[22] E. Mata, A.S. Kalagasidis, F. Johnsson, Building-stock aggregation through archetype buildings: France, Germany, Spain and the UK, Building and Environment 81 (2014) 270-282

[23] International Energy Agency Solar Heating and Cooling Task 47, 2014. Renovation of NonResidential Buildings towards Sustainable Standards. http://task47.iea-shc.org/publications. Last accessed: July 2016

[24] Commercial Buildings Energy Consumption Survey (CBECS), 2012. http://www.eia.gov/consumption/commercial/reports.cfm. Last accessed: July 2016

[25] M. Grosso, Urban form and renewable energy potential, Renewable Energy 15 (1998) 331-336

[26] CIBSE. Good practice guide 237: Natural ventilation in non-domestic buildings. A guide for designers, developers and owners. London, 1999

[27] V. Lo Verso, C. Reinhart, A rules of thumb-based design sequence for diffuse daylight, Lighting Research and Technology 42 (2010) 7-31

[28] L. Bellia, F. De Falco, F. Minichiello, Effects of solar shading devices on energy requirements of standalone office buildings for Italian climates, Applied Thermal Energy 54 (2013) 190-201

[29] E. Gratia, I. Bruyère, A. De Herde, How to use natural ventilation to cool narrow office buildings, Building and Environment 39 (2004) 1157-1170

[30] T. Schulze, U. Eicker, Controlled natural ventilation for energy efficient buildings, Energy and Buildings 56 (2013) 221-232 
[31] M. Grosso, Wind pressure distribution around buildings - a parametrical model, Energy and Buildings 18 (2) (1992) 201-231

[32] R. Ramponi, A. Angelotti, B. Blocken, Energy saving potential of night ventilation: Sensitivity to pressure coefficients for different European climates, Applied Energy 123 (2014) 185-195

[33] E. Ng, Policies and technical guidelines for urban planning of high-density cities - air ventilation assessment (AVA) of Hong Kong, Building and Environment 44 (2009) 1478-1488

[34] R. Guglielmetti, D. Macumber, N. Long, OpenStudio: An open source integrated analysis platform. Proceedings of the 12th Conference of International Building Performance Simulation Association 2011, Sydney, 14-16 November

[35] J. Zhai, M. Krarti, M.H. Johnson, Assess and implement natural and hybrid ventilation models in whole-building energy simulations, Energy and Buildings 49 (9) (2011) 2251-2261

[36] D. Coakley, P. Raftery, P. Molloy, Calibration of whole building energy simulation models: detailed case study of a naturally ventilated building using hourly measured data. In: Building simulation and optimization, Loughborough, UK (2012)

[37] L.C. Ng, A.K. Persily, S.J. Emmerich, Improving infiltration modeling in commercial building energy models, Energy and Buildings 88 (2015) 316-323

[38] IES LM-83-12. Approved method: IES Spatial Daylight Autonomy (sDA) and Annual Sunlight Exposure (ASE)

[39] T.Gibson, M. Krarti, Comparative analysis of prediction accuracy from daylighting simulation tools, Leukos 11 (2015) 49-60

[40] R. Kittler, Daylight prediction and assessment: theory and design practice, Architectural Science Review 50 (2) (2007) 94-99

[41] G. Ramos, E. Ghisi, Analysis of daylight calculated using the EnergyPlus programme, Renewable and Sustainable Energy Reviews 14 (2010) 1948-1958

[42] J.F. Nicol, M.A. Humphreys, Thermal comfort as part of a self-regulating system, in: Proceedings of the CIB Symposium on Thermal Comfort, Building Research Establishment, Watford, UK (1972)

[43] J.F. Nicol, M.A. Humphreys, Adaptive Thermal comfort and sustainable thermal standards for buildings, Energy and Buildings 34 (2002) 563-572 
[44] R.J. De Dear, G.S. Brager, Thermal comfort in naturally ventilated buildings: revisions to ASHRAE Standard 55, Energy and Buildings 34 (2002) 549-561

[45] U. Satish, M.J. Mendell, K. Shekhar, T. Hotchi, D. Sullivan, S. Streufert, W.J. Fisk, Is CO2 an indoor pollutant? Direct effects of low-to-moderate $\mathrm{CO} 2$ concentrations on human decision-making performance, Environmental Health Perspectives 120 (12) (2012) 1671-1677

[46] L. Edwards, P. Torcellini, A literature review of the effects of natural light on building occupants, National Renewable Energy Laboratory (2002), NREL/TP-550-30769 
Figure 1. Chart produced by David Taylor at

http://www.prooffreader.com/2013 1101 archive.html showing the relative population by

latitude in North America and Europe

Figure 2. Psychrometric Charts created by Climate Consultant software [21] comparing TMY data for climates considered in Europe and North America as 'Hot-Dry' climates: Madrid (left) and Albuquerque

Figure 3. Psychrometric Charts created by Climate Consultant software [21] showing TMY data for Riyadh - a Koppen-Geiger 'Hot-Dry' climate

Figure 4. Psychrometric Chart created by Climate Consultant software [21] showing TMY data for Hawaii - a Koppen-Geiger 'Hot-Humid' climate

Figure 5. Psychrometric Charts created by Climate Consultant software [21] comparing TMY data for Rome (left) and Atlanta (right)

Figure 6. Axonometric view of the base thermal model

Figure 7. Flow chart of the simulations framework

Figure 8. Screenshot of the urban grid. The study building is highlighted in red, together with wind angles reference system

Figure 9. Reference grids of sensor points for daylighting analyses (measures in metres)

Figure $10 . C_{p}$ values as a function of different UAR values and wind incident angles. Left: top window oriented due south. Right: top window oriented due $20^{\circ}$ to south

Figure 11. Givoni's bioclimatic charts for the best base cases (red dots) and WithVent cases (blue dots) for the different cities analyzed

Figure 12. IAQ matrix for the best WithVent models. On the columns: climate classification. On the rows: $\mathrm{ACH}$ (top two) and $\mathrm{CO}_{2}$ concentrations (bottom two)

Figure 13. Daylighting metrics for the best cases for both EU cities (left) and US cities (right). Solid bars: sDA index. Solid lines: ASE index 
Table 1. Cities representative of different mid-latitude climates with Köppen-Geiger style classifications

\begin{tabular}{llllll}
\hline $\begin{array}{l}\text { Hot dry/Mixed } \\
\text { dry }\end{array}$ & Hot humid & Mixed humid & Marine & Cold \\
\hline Madrid & Rome & Lyon & London & Stuttgart \\
& & & & \\
EU & LAT: $40.27 \mathrm{~N}$ & LAT: $41.47 \mathrm{~N}$ & LAT: $45.43 \mathrm{~N}$ & LAT: $51.90 \mathrm{~N}$ & LAT: $48.40 \mathrm{~N}$ \\
LON: $3.32 \mathrm{~W}$ & LON: $12.13 \mathrm{E}$ & LON: $5.40 \mathrm{E}$ & LON: $0.10 \mathrm{~W}$ & LON: $9.13 \mathrm{E}$ \\
HDD: $2023^{\circ} \mathrm{C}$ & HDD: $1525^{\circ} \mathrm{C}$ & HDD: $2588^{\circ} \mathrm{C}$ & HDD: $2968^{\circ} \mathrm{C}$ & HDD: $3490^{\circ} \mathrm{C}$ \\
CDD: $612^{\circ} \mathrm{C}$ & CDD: $555^{\circ} \mathrm{C}$ & CDD: $309^{\circ} \mathrm{C}$ & CDD: $44^{\circ} \mathrm{C}$ & CDD: $106^{\circ} \mathrm{C}$ \\
\hline Albuquerque & Atlanta & Baltimore & Seattle & Chicago \\
& & & & \\
US & LAT: $35.20 \mathrm{~N}$ & LAT: $33.39 \mathrm{~N}$ & LAT: $39.10 \mathrm{~N}$ & LAT: $47.27 \mathrm{~N}$ & LAT: $41.46 \mathrm{~N}$ \\
LON: $106.37 \mathrm{~W}$ & LON: $84.25 \mathrm{~W}$ & LON: $76.40 \mathrm{~W}$ & LON: $122.18 \mathrm{~W}$ & LON: $87.45 \mathrm{~W}$ \\
& HDD: $2261^{\circ} \mathrm{C}$ & HDD: $1497^{\circ} \mathrm{C}$ & HDD: $2537^{\circ} \mathrm{C}$ & HDD: $2627^{\circ} \mathrm{C}$ & HDD: $3506^{\circ} \mathrm{C}$ \\
CDD: $749^{\circ} \mathrm{C}$ & CDD: $1023^{\circ} \mathrm{C}$ & CDD: $682^{\circ} \mathrm{C}$ & CDD: $98^{\circ} \mathrm{C}$ & CDD: $468^{\circ} \mathrm{C}$ \\
\hline
\end{tabular}


Table 2. Climatic characteristics of the different sites (summer and winter daily averages)

\begin{tabular}{|c|c|c|c|c|c|}
\hline \multirow[t]{2}{*}{$\begin{array}{l}\text { Standard } \\
\text { "Koppen- } \\
\text { Geiger" } \\
\text { style } \\
\text { Classes }\end{array}$} & & $\begin{array}{l}\text { Dry bulb } \\
\text { temperature } \\
\left({ }^{\circ} \mathrm{C}\right)\end{array}$ & $\begin{array}{l}\text { Relative } \\
\text { humidity } \\
(\%)\end{array}$ & $\begin{array}{l}\text { Global } \\
\text { horizontal } \\
\text { radiation } \\
\left(\mathrm{Wh} \cdot \mathbf{m}^{-}\right. \\
\left.{ }^{2} \cdot \mathrm{hr}^{-1}\right)\end{array}$ & $\begin{array}{l}\text { Wind } \\
\text { speed } \\
\left(\mathbf{m} \cdot \mathbf{s}^{-1}\right)\end{array}$ \\
\hline & \multicolumn{5}{|c|}{ Summer } \\
\hline \multirow{2}{*}{$\begin{array}{l}\text { Hot } \\
\text { dry/Mixed } \\
\text { dry }\end{array}$} & Madrid Barajas Intl Arpt & 23.6 & 45.6 & 487.4 & 2.7 \\
\hline & Albuquerque Intl Arpt Isis & 24.3 & 41.8 & 529.1 & 4.1 \\
\hline \multirow[t]{2}{*}{ Hot humid } & Rome Fiumicino Intl Arpt & 23.3 & 76.0 & 437.2 & 3.3 \\
\hline & Atlanta Hartsfield Intl Arpt & 25.8 & 69.1 & 455.0 & 3.5 \\
\hline \multirow{2}{*}{$\begin{array}{l}\text { Mixed } \\
\text { humid }\end{array}$} & Lyon Satolas Intl Arpt & 20.3 & 69.4 & 378.2 & 2.7 \\
\hline & Baltimore Blt Washngtn IntL & 24.2 & 67.4 & 414.4 & 3.3 \\
\hline \multirow[t]{2}{*}{ Marine } & London Gatwick Intl Arpt & 16.3 & 73.8 & 307.7 & 2.9 \\
\hline & Seattle Seattle Tacoma Intl A & 17.4 & 66.0 & 381.6 & 3.9 \\
\hline \multirow[t]{4}{*}{ Cold } & Stuttgart Echterdingen Intl Arpt & 17.2 & 68.8 & 338.3 & 2.3 \\
\hline & Chicago Ohare Intl Ap & 22.3 & 70.0 & 405.9 & 4.3 \\
\hline & \multicolumn{5}{|c|}{ Winter } \\
\hline & & $\begin{array}{l}\text { Dry bulb } \\
\text { temperature } \\
\left({ }^{\circ} \mathrm{C}\right)\end{array}$ & $\begin{array}{l}\text { Relative } \\
\text { humidity } \\
(\%)\end{array}$ & $\begin{array}{l}\text { Global } \\
\text { horizontal } \\
\text { radiation } \\
\left(\mathrm{Wh} \cdot \mathbf{m}^{-}\right. \\
\left.{ }^{2} \cdot \mathbf{h r}^{-1}\right)\end{array}$ & $\begin{array}{l}\text { Wind } \\
\text { speed } \\
\left(\mathrm{m} \cdot \mathrm{s}^{-1}\right)\end{array}$ \\
\hline \multirow{2}{*}{$\begin{array}{l}\text { Hot } \\
\text { dry/Mixed } \\
\text { dry }\end{array}$} & Madrid Barajas Intl Arpt & 6.1 & 75.2 & 209.9 & 2.6 \\
\hline & Albuquerque Intl Arpt Isis & 3.0 & 50.3 & 335.1 & 3.3 \\
\hline \multirow[t]{2}{*}{ Hot humid } & Rome Fiumicino Intl Arpt & 8.9 & 79.4 & 196.0 & 3.8 \\
\hline & Atlanta Hartsfield Intl Ap & 6.5 & 62.1 & 281.0 & 4.8 \\
\hline \multirow{2}{*}{$\begin{array}{l}\text { Mixed } \\
\text { humid }\end{array}$} & Lyon Satolas Intl Arpt & 3.4 & 86.1 & 124.0 & 2.8 \\
\hline & Baltimore Blt Washngtn IntL & 1.3 & 62.2 & 223.3 & 4.5 \\
\hline \multirow[t]{2}{*}{ Marine } & London Gatwick Intl Arpt & 4.5 & 84.8 & 94.3 & 3.3 \\
\hline & Seattle Seattle Tacoma Intl A & 5.2 & 80.1 & 135.1 & 3.8 \\
\hline \multirow[t]{2}{*}{ Cold } & Stuttgart Echterdingen Intl Arpt & 0.9 & 81.9 & 113.3 & 3.3 \\
\hline & Chicago Ohare Intl Ap & -3.6 & 70.7 & 200.3 & 4.7 \\
\hline
\end{tabular}


Table 3. Outdoor air temperature frequency distribution of the different sites

\begin{tabular}{|c|c|}
\hline \multirow{6}{*}{ Hot dry/mixed dry } & DRY-BULB TEMP (degrees C) \\
\hline & 4\% $\square$ \\
\hline & 53吅 $\square$ \\
\hline & $21 \% \square \quad 20-24$ \\
\hline & $22 \% \square \quad 24-38$ \\
\hline & $0 \% \square>38$ \\
\hline
\end{tabular}

Albuquerque

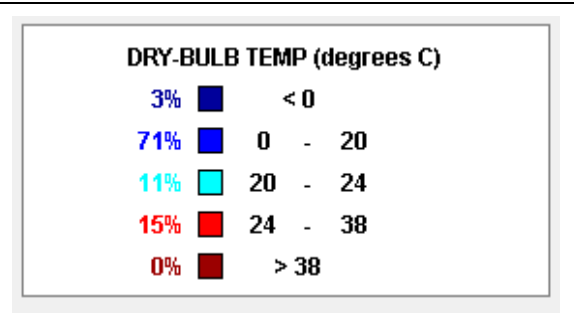

Madrid

\begin{tabular}{|c|c|c|}
\hline \multirow[t]{2}{*}{ Hot humid } & 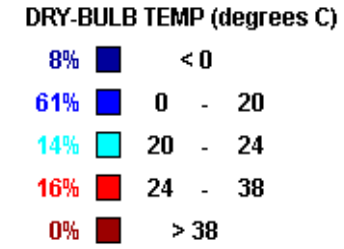 & 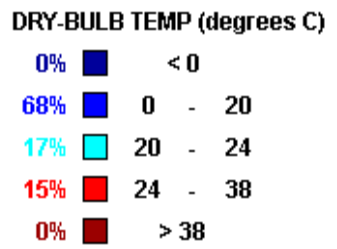 \\
\hline & Atlanta & Rome \\
\hline \multirow[t]{2}{*}{ Mixed humid } & 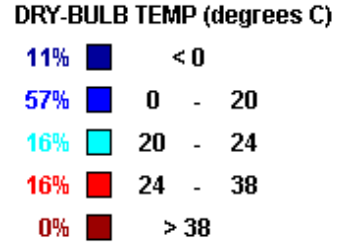 & 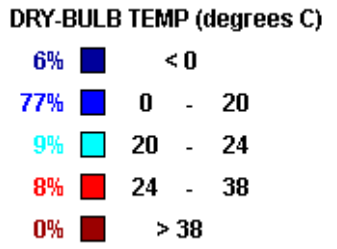 \\
\hline & Baltimore & Lyon \\
\hline \multirow[t]{2}{*}{ Marine } & 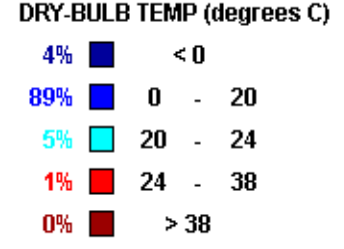 & 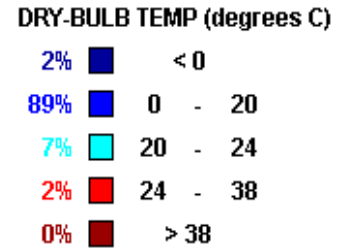 \\
\hline & Seattle & London \\
\hline \multirow[t]{2}{*}{ Cold } & 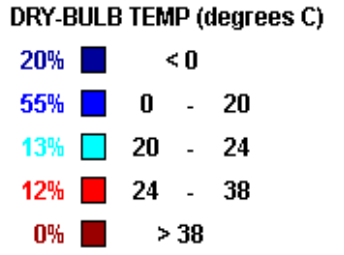 & 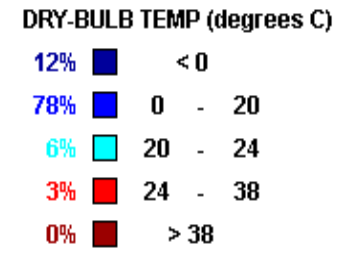 \\
\hline & Chicago & Stuttgart \\
\hline
\end{tabular}


Table 4. Amount of office floor area built within each reference period [2-3]

\begin{tabular}{llll}
\hline & Pre-1980 & Post-1980 & $\begin{array}{l}\text { New } \\
\text { construction } \\
\text { (after 2000) }\end{array}$ \\
\hline$E U$ & $56 \%$ & $28 \%$ & $16 \%$ \\
\hline$U S$ & $46 \%$ & $38 \%$ & $16 \%$ \\
\hline
\end{tabular}


Table 5. Construction types [2-3]

\begin{tabular}{|c|c|c|c|c|}
\hline & & Pre-1980 & Post-1980 & $\begin{array}{l}\text { New } \\
\text { construction }\end{array}$ \\
\hline \multirow{4}{*}{$\mathbf{E U}$} & Walls & $\begin{array}{l}\text { Concrete cladding } \\
\text { on concrete pillars } \\
\text { and beams }\end{array}$ & $\begin{array}{l}\text { Concrete cladding on } \\
\text { concrete pillars and } \\
\text { beams }\end{array}$ & $\begin{array}{l}\text { Aluminium and } \\
\text { glass façade on } \\
\text { concrete pillars } \\
\text { and beams }\end{array}$ \\
\hline & Roof & $\begin{array}{l}\text { Flat concrete roof } \\
\text { with bitumised } \\
\text { surface }\end{array}$ & $\begin{array}{l}\text { Flat concrete roof with } \\
\text { bitumised surface }\end{array}$ & $\begin{array}{l}\text { Flat concrete roof } \\
\text { with bitumised } \\
\text { surface }\end{array}$ \\
\hline & Floors & $\begin{array}{l}\text { As for roof, but } \\
\text { with tiles in place } \\
\text { of bitumen }\end{array}$ & $\begin{array}{l}\text { As for roof, but with } \\
\text { tiles in place of } \\
\text { bitumen }\end{array}$ & $\begin{array}{l}\text { As for roof, but } \\
\text { with tiles in place } \\
\text { of bitumen }\end{array}$ \\
\hline & Windows & $\begin{array}{l}\text { Double-glazed with } \\
\text { PVC frame }\end{array}$ & $\begin{array}{l}\text { Double-glazed with } \\
\text { aluminium frame }\end{array}$ & $\begin{array}{l}\text { Double-glazed } \\
\text { with aluminium } \\
\text { frame }\end{array}$ \\
\hline \multirow{4}{*}{ US } & Walls & Steel framed walls & Steel framed walls & Mass walls \\
\hline & Roof & $\begin{array}{l}\text { Metal decking with } \\
\text { insulation above it }\end{array}$ & $\begin{array}{l}\text { Metal decking with } \\
\text { insulation above it }\end{array}$ & $\begin{array}{l}\text { Metal decking } \\
\text { with insulation } \\
\text { above it }\end{array}$ \\
\hline & Floors & $\begin{array}{l}\text { Carpet on concrete } \\
\text { slab }\end{array}$ & $\begin{array}{l}\text { Carpet on concrete } \\
\text { slab }\end{array}$ & $\begin{array}{l}\text { Carpet on } \\
\text { concrete slab }\end{array}$ \\
\hline & Windows & $\begin{array}{l}\text { Single glazed for } \\
\text { climate zones } 1-4 \text {, } \\
\text { double glazed for } \\
\text { climate zones 5-8 }\end{array}$ & Double glazed & Double glazed \\
\hline
\end{tabular}


Table 6. U-values of the building envelope components for different cities and vintage periods $\left(\mathrm{W} \cdot \mathrm{m}^{-2} \cdot \mathrm{K}^{-1}\right)[2-3]$

\begin{tabular}{|c|c|c|c|c|c|}
\hline & & & Walls & Roof & Windows \\
\hline \multirow{10}{*}{ Pre-1980 } & \multirow{5}{*}{$E U$} & Madrid & 2.20 & 1.40 & 5.80 \\
\hline & & Rome & 1.20 & 1.30 & 5.50 \\
\hline & & Lyon & 2.10 & 1.80 & 5 \\
\hline & & London & 1.70 & 1.80 & 4.90 \\
\hline & & Stuttgart & 1.50 & 1 & 2.90 \\
\hline & \multirow{5}{*}{$U S$} & Albuquerque & 1.04 & 0.50 & 6.93 \\
\hline & & Atlanta & 1.28 & 0.57 & 6.93 \\
\hline & & Baltimore & 1.01 & 0.49 & 6.93 \\
\hline & & Seattle & 0.99 & 0.48 & 6.93 \\
\hline & & Chicago & 0.89 & 0.41 & 3.52 \\
\hline \multirow{10}{*}{ Post-1980 } & \multirow{5}{*}{$E U$} & Madrid & 1.80 & 1 & 3.30 \\
\hline & & Rome & 0.80 & 0.80 & 4.20 \\
\hline & & Lyon & 1.20 & 0.80 & 3.40 \\
\hline & & London & 0.70 & 0.50 & 4.60 \\
\hline & & Stuttgart & 0.90 & 0.50 & 1.90 \\
\hline & \multirow{5}{*}{$U S$} & Albuquerque & 1.08 & 0.33 & 4.09 \\
\hline & & Atlanta & 1.64 & 0.41 & 4.09 \\
\hline & & Baltimore & 0.68 & 0.33 & 3.35 \\
\hline & & Seattle & 0.57 & 0.36 & 4.09 \\
\hline & & Chicago & 0.57 & 0.30 & 3.35 \\
\hline \multirow{10}{*}{$\begin{array}{c}\text { New } \\
\text { construction }\end{array}$} & \multirow{5}{*}{$E U$} & Madrid & 0.90 & 0.6 & 2.80 \\
\hline & & Rome & 0.60 & 0.60 & 3.60 \\
\hline & & Lyon & 0.40 & 0.30 & 2.70 \\
\hline & & London & 0.40 & 0.20 & 1.80 \\
\hline & & Stuttgart & 0.40 & 0.30 & 1.30 \\
\hline & \multirow{5}{*}{$U S$} & Albuquerque & 0.85 & 0.36 & 3.23 \\
\hline & & Atlanta & 0.85 & 0.36 & 3.23 \\
\hline & & Baltimore & 3.29 & 0.36 & 3.23 \\
\hline & & Seattle & 0.85 & 0.36 & 3.23 \\
\hline & & Chicago & 0.85 & 0.36 & 3.23 \\
\hline
\end{tabular}


Table 7. Building features used for the parametric analysis

\begin{tabular}{|c|c|c|}
\hline Parameters & Values & Variations \\
\hline $\begin{array}{l}\text { Constructions representative of } \\
\text { three vintage periods }\end{array}$ & pre 1980; Post 1980; New (post 2000) & 3 \\
\hline Urban Aspect Ratios (UAR) & $\begin{array}{l}\text { Isolated buildings; UAR=0.5; UAR=1; } \\
\text { UAR }=2\end{array}$ & 4 \\
\hline Floor dimensions $\left(1000 \mathrm{~m}^{2}\right)$ & $67 \mathrm{~m} \times 15 \mathrm{~m} ; 50 \mathrm{~m} \times 20 \mathrm{~m} ; 40 \mathrm{~m} \times 25$ & 3 \\
\hline $\begin{array}{l}\text { Overhangs Projection Factor } \\
\text { (PF) }\end{array}$ & no overhangs; $P F=0.5 ; P F=1$ & 3 \\
\hline Window to Wall Ratio (WWR) & WWR=0.3; WWR=0.4; WWR=0.5 & 3 \\
\hline Window Opening Area (WOA) ${ }^{*}$ & WOA=0.10; WOA=0.20; WOA=0.30 & 3 \\
\hline \multicolumn{2}{|c|}{ Number of models simulated per city. Base case } & 324 \\
\hline \multicolumn{2}{|c|}{ Number of models simulated per city. WithVent case } & 972 \\
\hline
\end{tabular}


Table 8. Building rotation with respect to the north direction (positive values are clockwise)

\begin{tabular}{llll}
\hline No rotation & $\mathbf{2 0}^{\circ}$ & $\mathbf{6 0}^{\circ}$ & $\mathbf{- 2 5}^{\circ}$ \\
\hline Madrid & Rome & Seattle & London \\
Lyon & & & Stuttgart \\
Albuquerque & & & \\
Atlanta & & & \\
Baltimore & & & \\
Chicago & & & \\
\hline
\end{tabular}


Table 9. Simulation assumptions (from [2-3])

\begin{tabular}{|c|c|c|c|c|c|c|c|}
\hline & People & Appliances & $\begin{array}{l}\text { Artificial } \\
\text { lighting }\end{array}$ & Infiltrations & Ventilation & $\begin{array}{l}\text { Occupancy } \\
\text { period }\end{array}$ & $\begin{array}{l}\text { Outdoor } \mathrm{CO}_{2} \\
\text { concentration }\end{array}$ \\
\hline$E U$ & $\begin{array}{l}21 \\
\mathrm{~m}^{2} / \text { person) }\end{array}$ & $12.5 \mathrm{~W} / \mathrm{m}^{2}$ & 10.8 & $0.15 \mathrm{ACH}$ & $\begin{array}{l}40 \mathrm{~m}^{3} / \mathrm{h} \\
\text { person } \\
\text { from } \\
\text { outside air }\end{array}$ & $\begin{array}{l}\text { Weekdays } \\
: 8: 30- \\
12: 30 \text { and } \\
13: 30- \\
17: 30\end{array}$ & $400 \mathrm{ppm}\left({ }^{2}\right)$ \\
\hline$U S$ & $\begin{array}{l}18.6 \\
\mathrm{~m}^{2} / \text { person }\end{array}$ & $10.8 \mathrm{~W} / \mathrm{m}^{2}$ & $\begin{array}{l}10.8 \\
\mathrm{~W} / \mathrm{m}^{2}\end{array}$ & $0.25 \mathrm{ACH}$ & $\begin{array}{l}9.4 \mathrm{l} / \mathrm{s} \text { per } \\
\text { person } \\
\text { from } \\
\text { outside air }\end{array}$ & $\begin{array}{l}\text { Weekdays } \\
: 9: 00- \\
13: 00 \\
\text { and 14:00- } \\
18: 00\end{array}$ & $400 \mathrm{ppm}\left({ }^{2}\right)$ \\
\hline (1) & $\begin{array}{l}\text { the original val } \\
\text { incandescent bu } \\
\text { this value is col }\end{array}$ & $\begin{array}{l}\text { of } 16 \mathrm{~W} / \mathrm{m}^{2} \\
\mathrm{~s} \text { typically us } \\
\text { dered as an a }\end{array}$ & $n$ offices & $.8 \mathrm{~W} / \mathrm{m}^{2} \mathrm{bc}$ & $\begin{array}{l}\text { it is co } \\
\text { [26] }\end{array}$ & & halogen \\
\hline
\end{tabular}




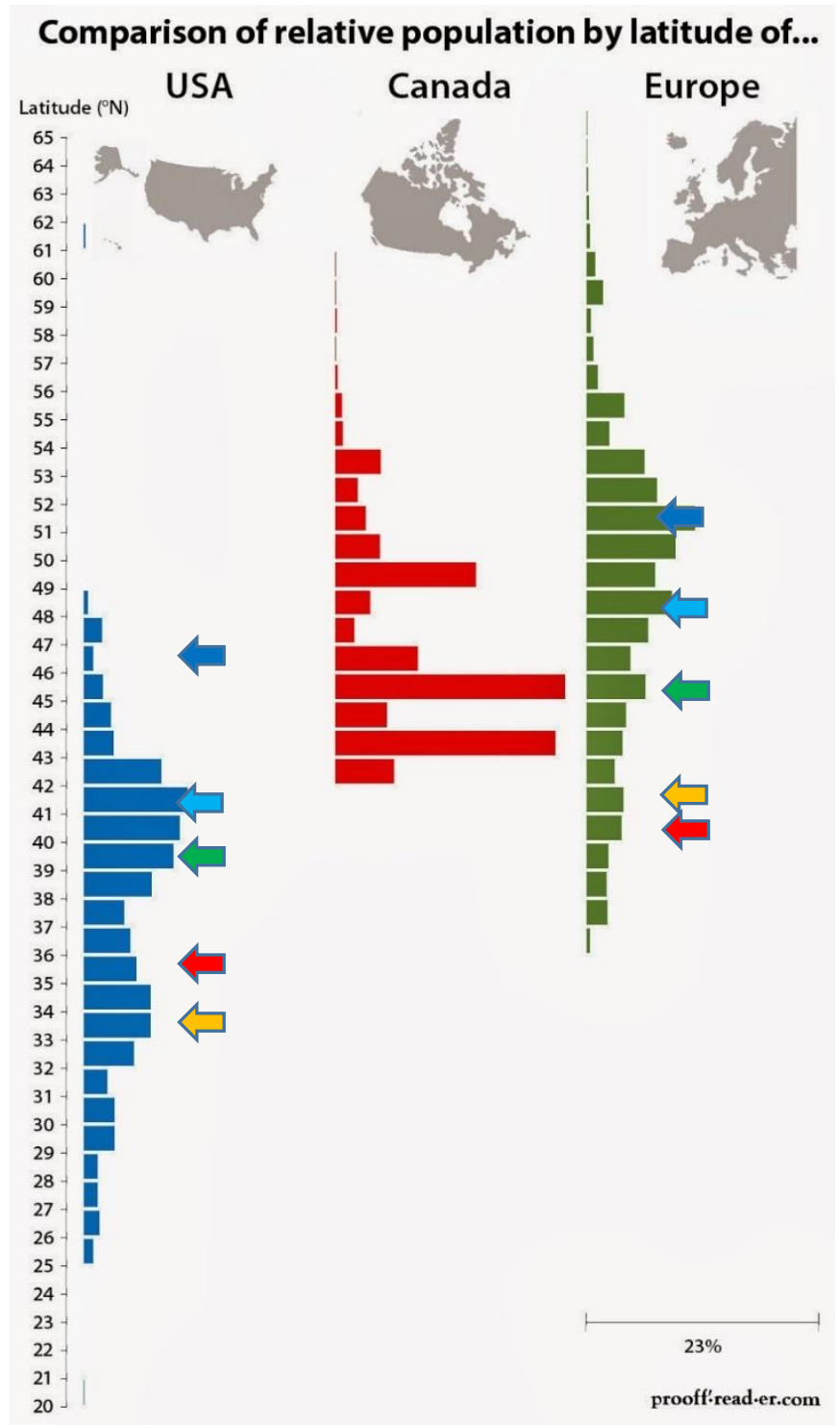

Figure 1. Chart produced by David Taylor at http://www.prooffreader.com/2013_11_01_archive.html showing the relative population by latitude in North America and Europe 

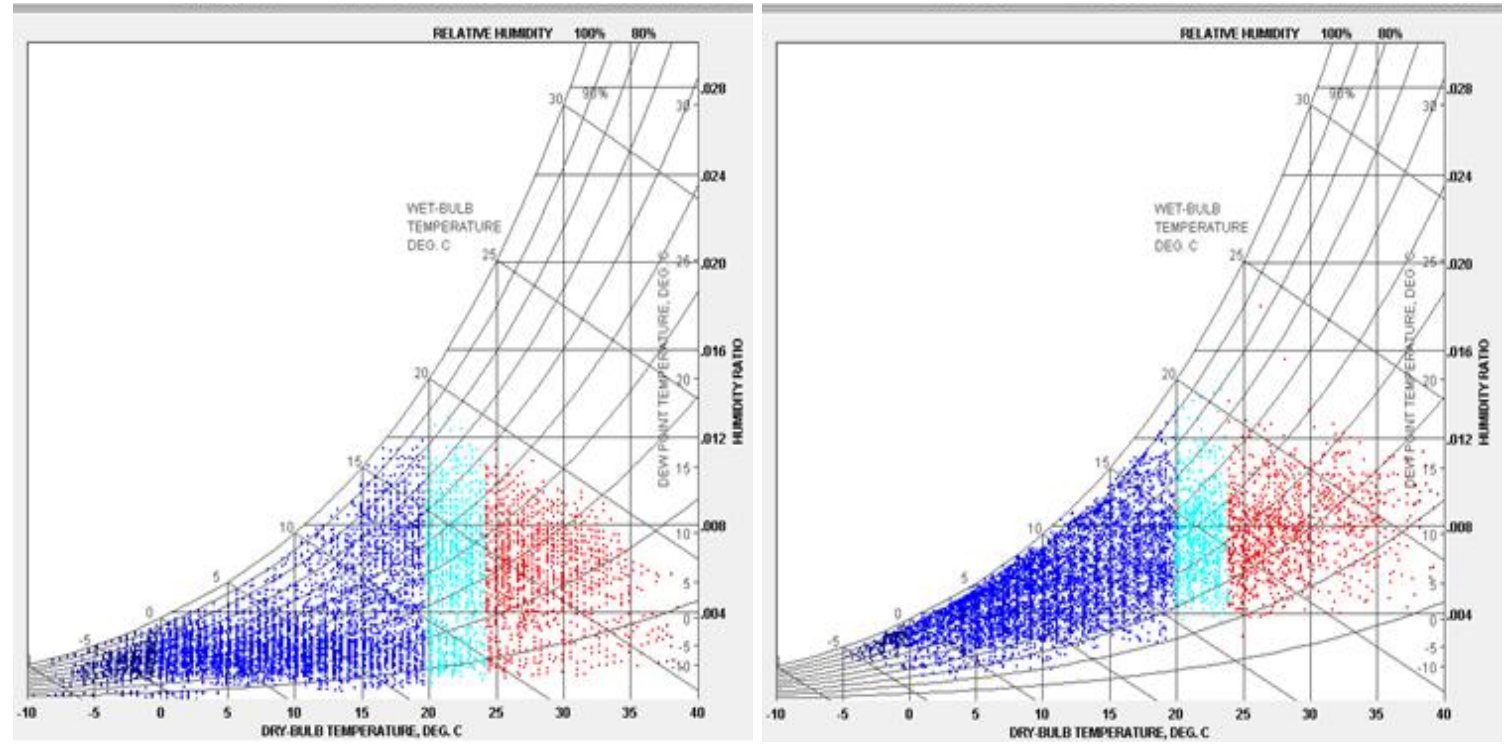

Figure 2. Psychrometric Charts created by Climate Consultant software [21] comparing TMY data for climates considered in Europe and North America as 'Hot-Dry' climates: Madrid (left) and Albuquerque 


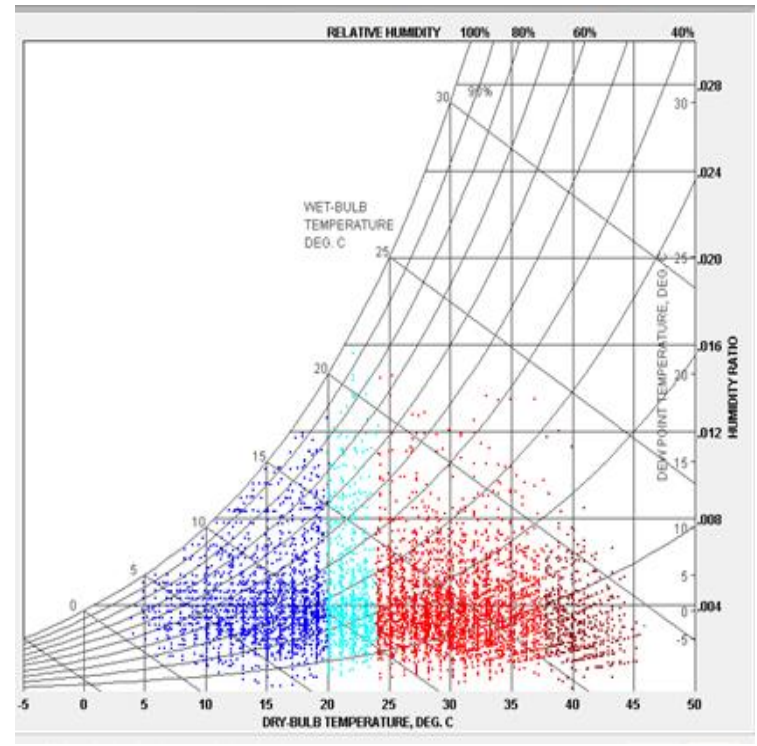

Figure 3. Psychrometric Charts created by Climate Consultant software [21] showing TMY data for Riyadh - a Koppen-Geiger 'Hot-Dry' climate 


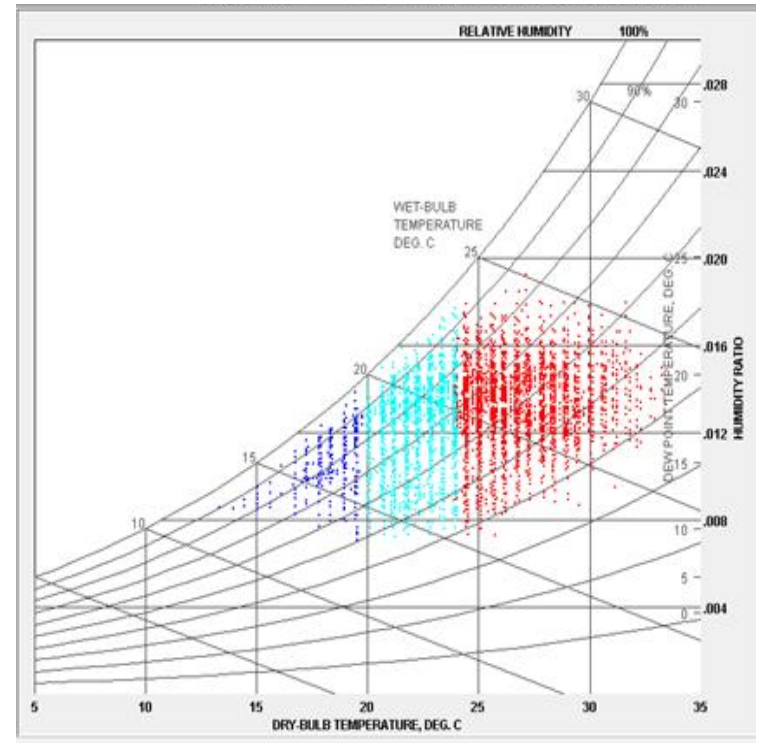

Figure 4. Psychrometric Chart created by Climate Consultant software [21] showing TMY data for Hawaii - a Koppen-Geiger 'Hot-Humid' climate 

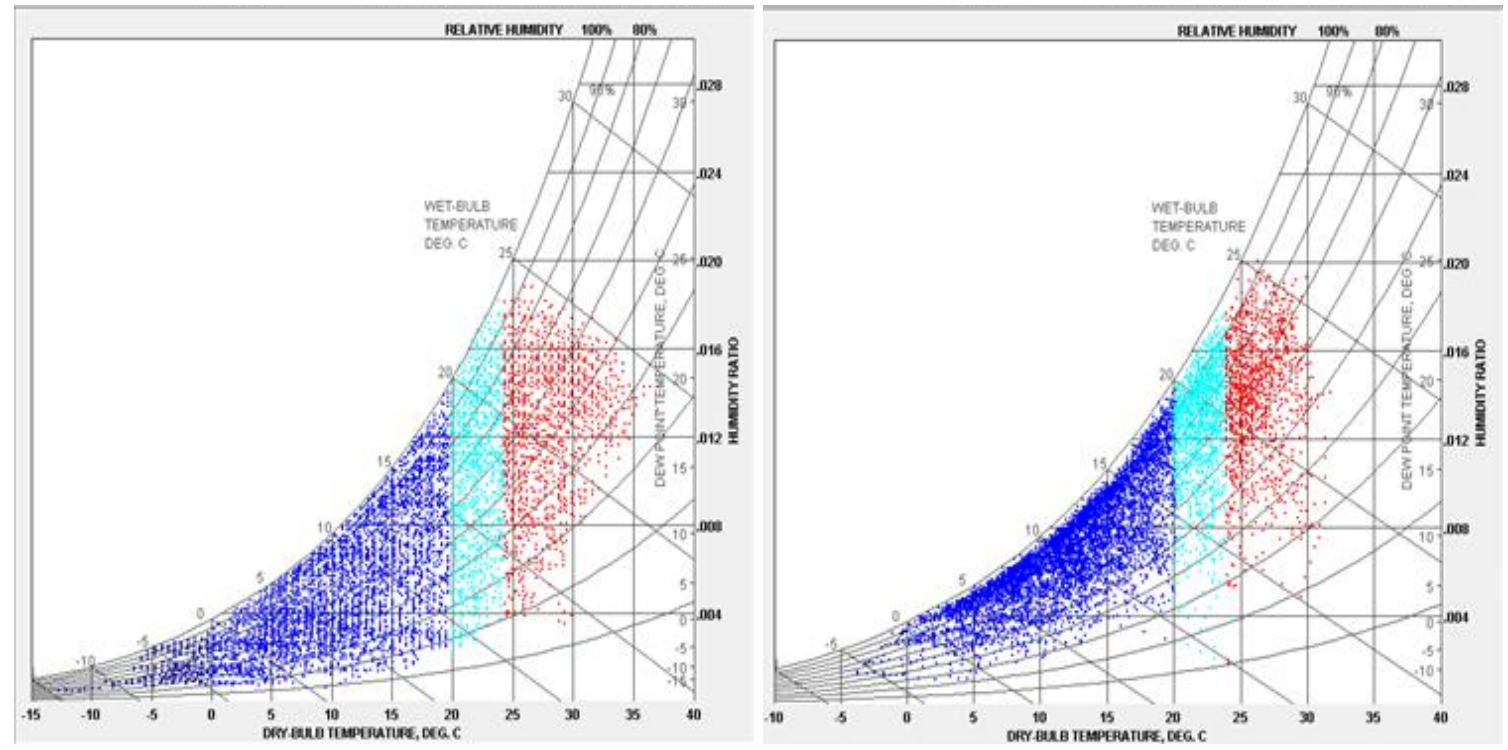

Figure 5. Psychrometric Charts created by Climate Consultant software [21] comparing TMY data for Rome (left) and Atlanta (right) 


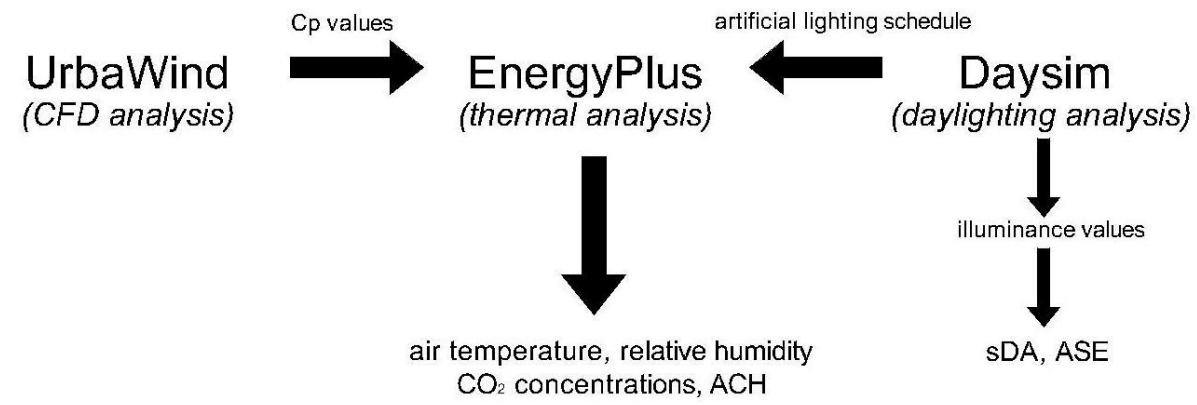

Figure 7. Flow chart of the simulations framework 


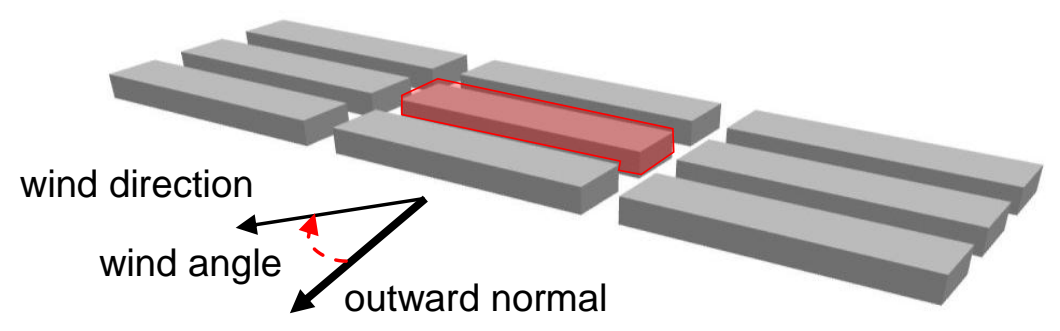

Figure 8. Screenshot of the urban grid. The study building is highlighted in red, together with wind angles reference system 

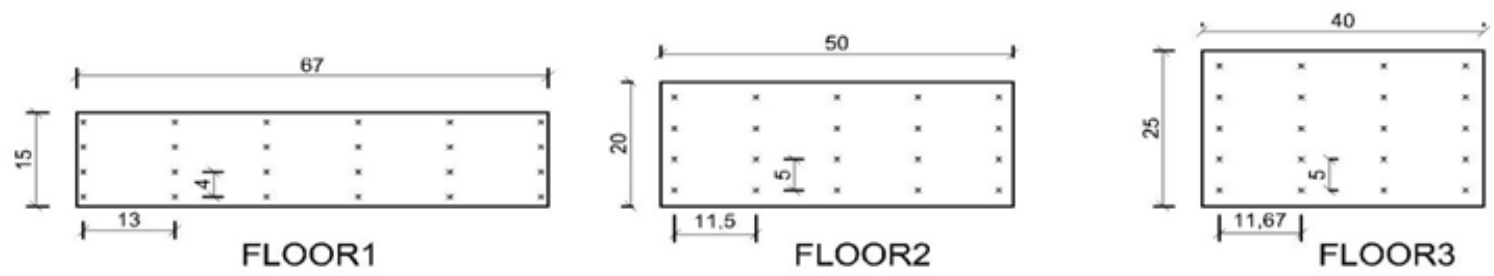

Figure 9. Reference grids of sensor points for daylighting analyses (measures in metres) 

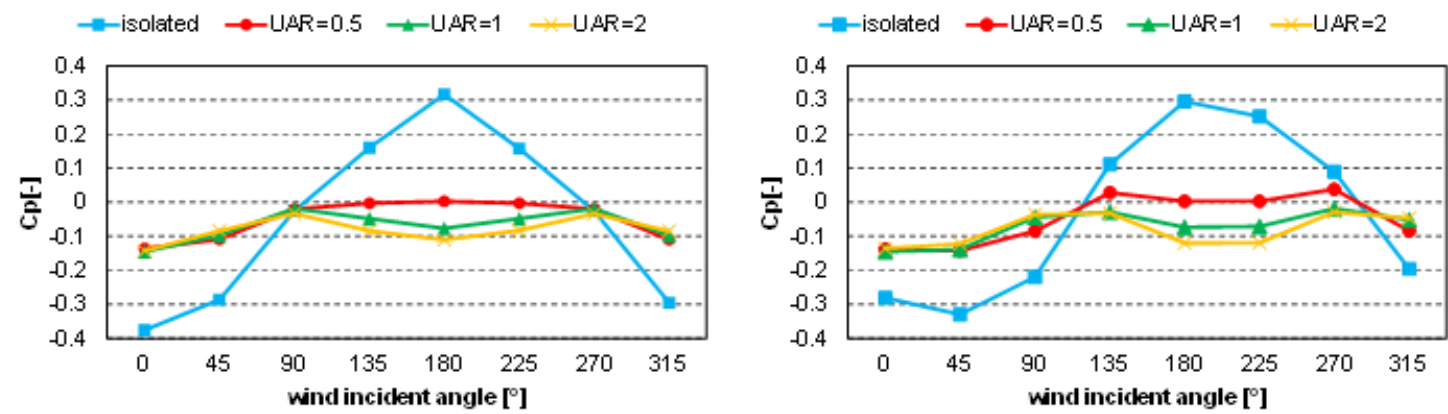

Figure $10 . C_{p}$ values as a function of different UAR values and wind incident angles. Left: top window oriented due south. Right: top window oriented due $20^{\circ}$ to south 


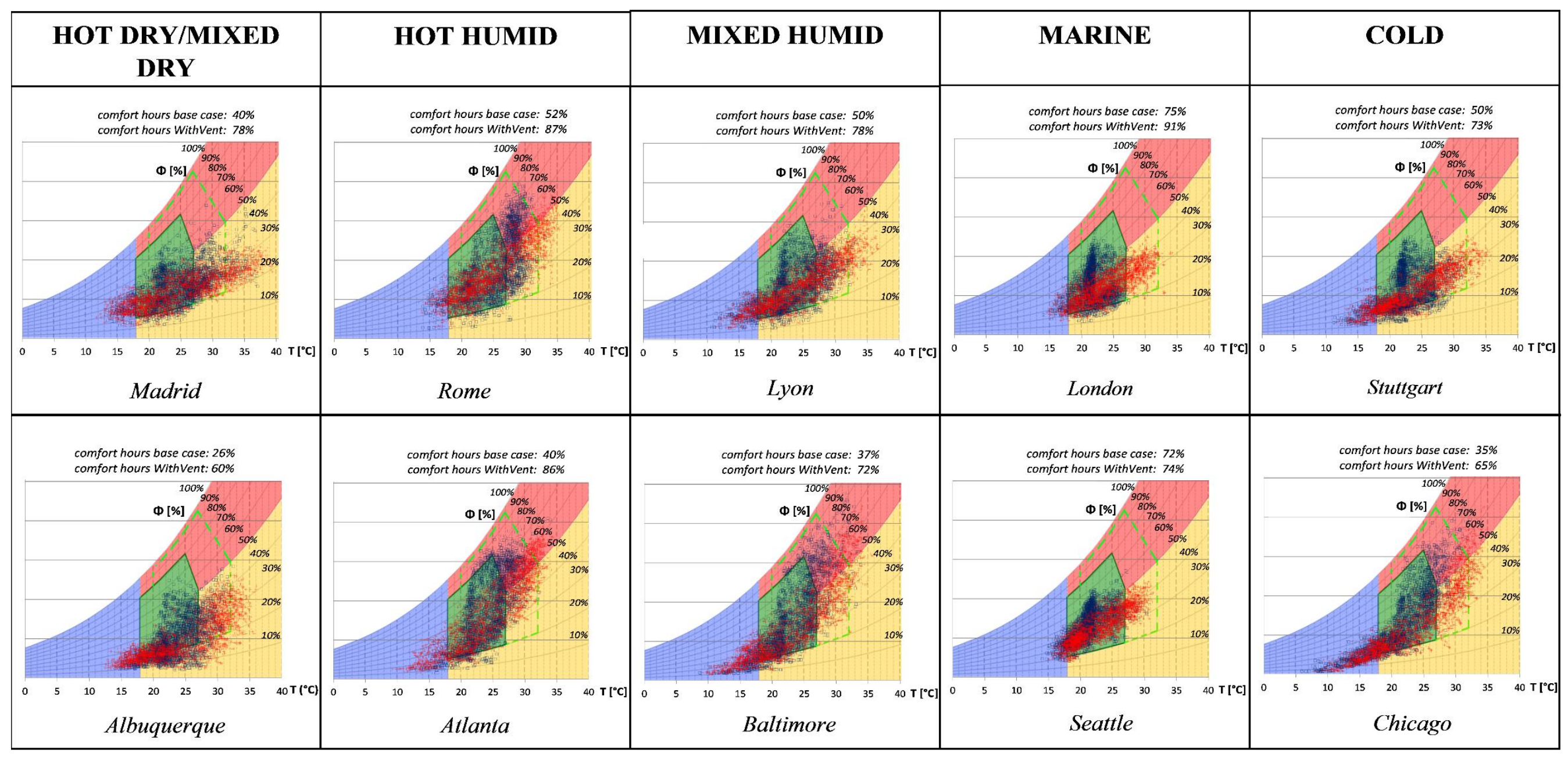

\section{LEGEND:}

Heating zone

Cooling dehumidifying zone

Cooling humidifying zone
Comfort zone

- - - Extended comfort zone $\square \quad$ Best base case

Best WithVent case

Figure 11. Givoni's bioclimatic charts for the best base cases (red dots) and WithVent cases (blue dots) for the different cities analyzed 
ACCEPTED MANUSCRIPT

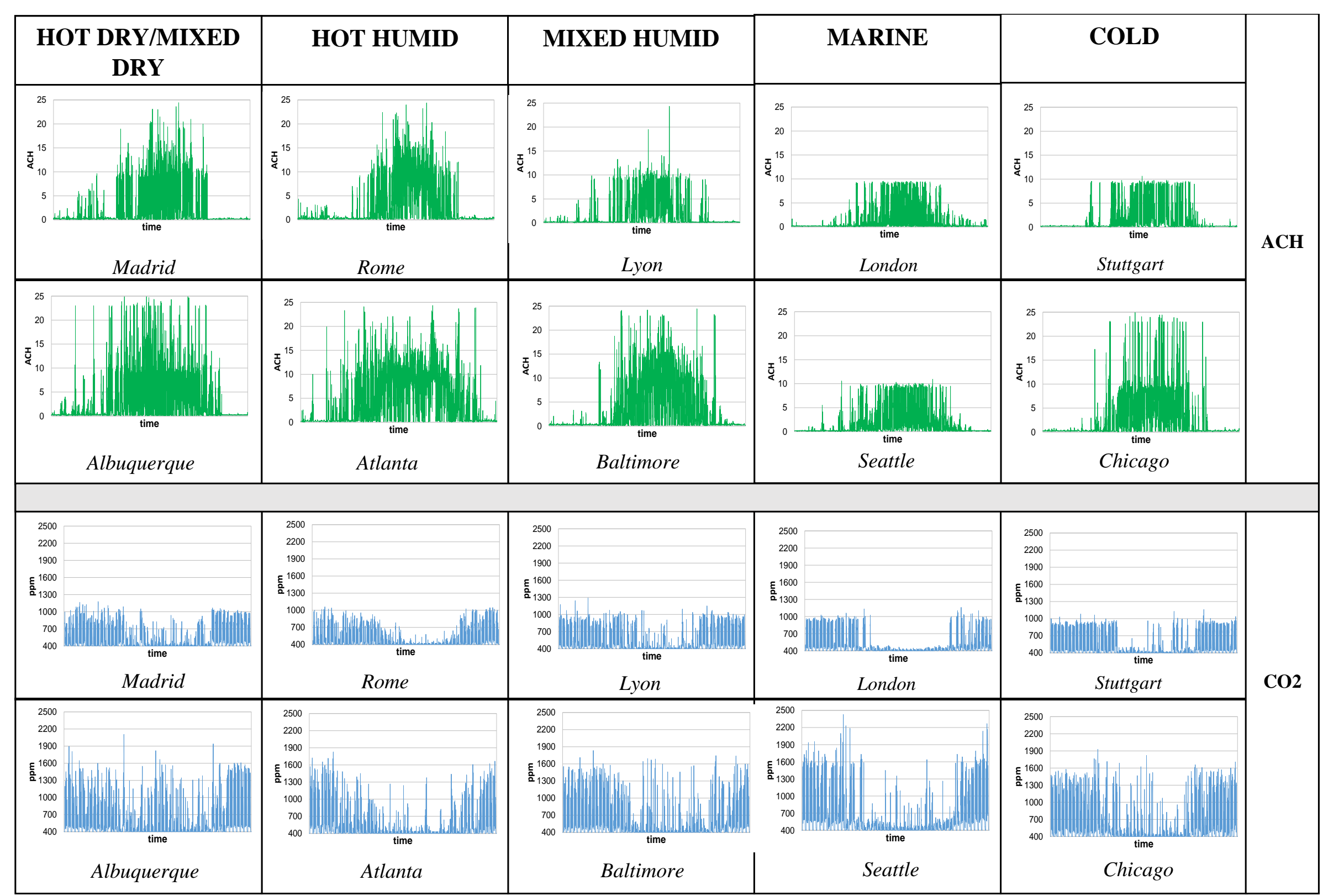

Figure 12. IAQ matrix for the best WithVent models. On the columns: climate classification. On the rows: $\mathrm{ACH}$ (top two) and $\mathrm{CO}_{2}$ concentrations (bottom two) 

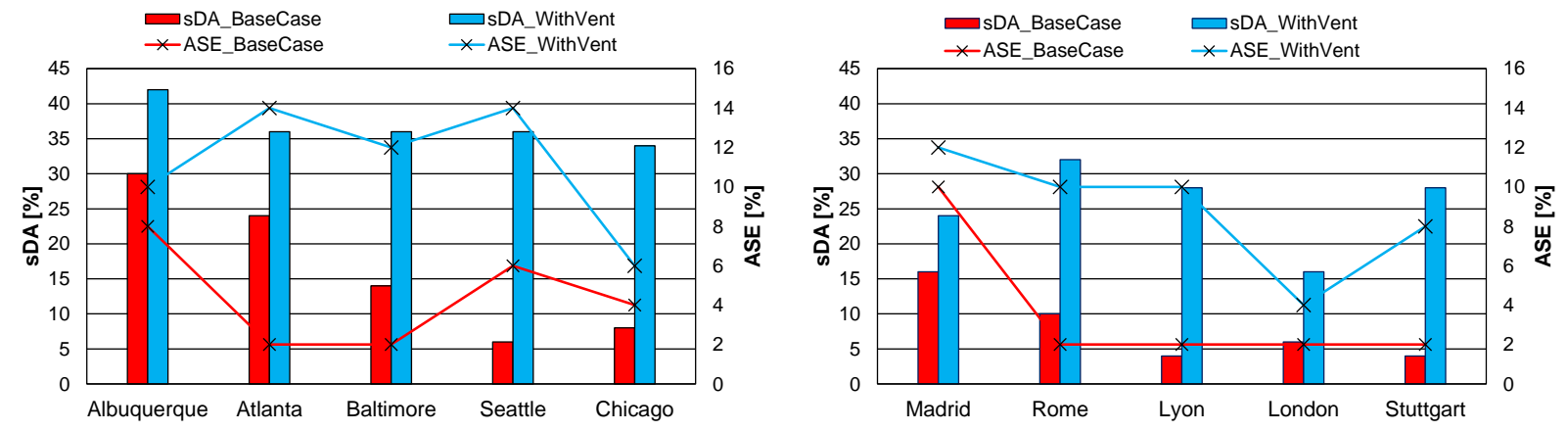

Figure 13. Daylighting metrics for the best cases for both EU cities (left) and US cities (right). Solid bars: sDA index. Solid lines: ASE index 